\title{
IFRS Adoption, Earnings Management and Investor Protection in Several Asian Countries
}

\author{
Fathiah Rahmaningtyas ${ }^{1}$, Aria Farah Mita ${ }^{1 *}$ \\ ${ }^{1}$ Faculty of Economics and Business, Universitas Indonesia, Depok 16424, Indonesia \\ ${ }^{*}$ Corresponding Author: aria.farahmita@ui.ac.id
}

\begin{abstract}
This research aims to examine whether the adoption of IFRS decreases earnings management in companies from Asian countries. It also considers the impact of country-level investor protection on the adoption of IFRS that would affect earnings management. The Kothari, Leone and Wasley ${ }^{1}$ model is used to calculate discretionary accruals to measure earnings management. Unlike most of the previous research, the result shows that earnings management is higher after the adoption of IFRS than before IFRS was adopted. This increase in earnings management is probably due to IFRS adoption, which is still at an early stage. Principle-based IFRS characteristics provide a broader judgment area for management. Thus, in the transition period of IFRS adoption, management may use its discretion in preparing financial statements. However, the positive relation of IFRS with earnings management level is lower in countries with a strong investor protection.
\end{abstract}

Keywords: IFRS Adoption; Earnings Management; Investor Protection.

\section{INTRODUCTION}

Financial statements are used by investors to make economic decisions. Currently, the international market is more integrated because it is easier to trade in many countries. The function of financial statements will increase if the same language is used throughout the world, as this will increase comparability. This could be achieved through a global accounting standard.

Acknowledging the urgency for international accounting standards, the International Accounting Standards Board (IASB) established International Financial Reporting Standards (IFRS) in 2001. IASB expects that IFRS will be adopted by all countries, meaning all firms will prepare financial statements that can be compared with other financial statements in other countries. This adoption could increase the benefit of financial reporting to investors ${ }^{2}$.

Financial statements are also a form of management's responsibility to shareholders. The separation of ownership and management in firms might raise conflicts because each party tries to maximize their own interests, which could be contradictory ${ }^{3}$.

One behavior of management in maximizing their own interest is through opportunistic earnings management. Opportunistic earnings management could decrease the quality of financial reporting ${ }^{4}$. In theory, IFRS adoption will limit management in undertaking earnings management and increase the quality of disclosed information ${ }^{5}$. Several IFRS main features are the principle-based approach and increasing mandatory disclosure. The chosen accounting measurements have to be more representative of the economic performance of entities. The use of fair value in IFRS is considered to reflect the firm's condition more accurately because they have to assess their assets and liabilities based on the market's fair value. However, the flexibility in the principal basis of IFRS, in addition to lax IFRS enforcement, might allow management to opportunistically manage earnings ${ }^{6}$.

Many empirical studies have shown that the incidence of earnings management decreased after IFRS was adopted $^{5-8}$. However, other studies have claimed that IFRS adoption does not affect or increase the level of earnings management $t^{9-11}$. Barth, Landsman, and Lang $^{6}$ explain that the different results are possibly due to the gradual transition from local accounting standards to IFRS and the lack of infrastructure to enforce IFRS.

There are three factors that affect accounting quality: the quality of the accounting standards used, the legal and politic system in a country, and the incentive from financial reporting ${ }^{12}$. Management's opportunist action can be avoided if there are effective laws and regulations that protect the external parties of firms. Several studies have found that earnings management activity is lower in countries with a strong investor protection compared to countries that have a weaker investor protection ${ }^{13-16}$.

Houqe, Dunstan, and Karim $^{17}$ investigated the effect of investor protection at a country level on the relationship between IFRS adoption and earnings management in 46 countries. They found that the level of earnings management decreased when a country adopted IFRS accompanied by a strong investor protection. The finding is based on the argument that accounting is also affected by the environment. 
The objective of this research is to test whether IFRS adoption decreases the level of earnings management in Indonesia, Malaysia, Philippines, Taiwan, Korea, and Hong Kong. Furthermore, this research also considers the effect of investor protection on the relation between IFRS adoption and earnings management. The six countries are chosen due to there still being few studies that use those six countries as the subjects. Most IFRS adoption research focuses on European countries. Earnings management is measured by calculating the absolute discretionary accrual, and the purpose of this research is to see the magnitude of the level of earnings management.

The proxy for investor protection is taken from the investor protection index that was issued by the Doing Business project under the World Bank. This index is a development from a study by Djankov, La Porta, Lopez-deSilanes, and Shleifer ${ }^{18}$. It measures the legal protection for investors against firms' self-dealing actions. The data for this index were gathered from questionnaires that were given to corporate and securities companies' lawyers, and the index is based on security regulations, corporate law, the code of civil procedure, and judiciary regulations.

\section{LITERATURE REVIEW AND HYPOTHESIS DEVELOPMENT}

IFRS has been adopted by over a hundred countries. However, there are critics of the establishment of international accounting standards, which as a solution, is considered too simple to deal with a complex problem ${ }^{19}$. If the main priority is the comparability of financial statements, it is feared that financial statements cannot represent firms' performance more accurately.

Based on the economic theory of networks, a country will adopt IFRS if its neighbouring countries or other countries that are its trading partners also adopt IFRS ${ }^{20}$. Countries with weak investor protection also tend to adopt IFRS compared to countries with stronger investor protection ${ }^{21}$. It can be seen that high-quality accounting standards are used as a tool that completes investor protection.

A literature study by Palea ${ }^{22}$ concluded that mandatory IFRS adoption in the European Union increased the quality of financial reporting, one feature of which is the value relevance. Other studies have also found that the adoption of IFS resulted in a lower level of earnings management, increased punctuality of loss recognition, and a more precise accounting value relevance ${ }^{5,7}$. Moreover, there are other factors that influence earnings management, namely, corporate governance and the foreign capital market ${ }^{7}$.

However, there is also empirical evidence that finds IFRS adoption does not affect or decrease the level of earnings management. Van tendeloo and Vanstraele ${ }^{9}$ found a higher level of discretionary accruals after IFRS adoption in Germany. Jeanjean and Stolowy ${ }^{11}$ also found that IFRS adoption in the UK and Australia did not affect the level of earnings management, and it increased the level of earnings management in France.

Even though there are debates on the effect of IFRS adoption, IASB developed IFRS with the purpose of establishing high-quality accounting standards and higher transparency. Therefore, this research proposes the first hypothesis as follows:

H1: IFRS adoption is negatively associated with the level of opportunistic earnings management.

Soderstrom and Sun ${ }^{12}$ explained that the application of accounting standards alone is not enough to influence the quality of financial reporting. Palea ${ }^{22}$ argued that the result of IFRS adoption depends on the firm's institutional system. Accounting figures are formed by the level of investor protection that confirms to a country's legal system and corporate law $^{23}$. Regulation, capital market law, economy and politics, and a taxation regulation system create an incentive that influences the behavior of corporate executives, investors, and other capital market players. Those incentives influence how management reports accounting figures through accounting policy selection. Bushman and Piotroski ${ }^{23}$ found that firms in countries with a strict legal system tend to be more conservative in financial reporting compared to countries with a weaker legal system.

Research has found that in 32 countries, the level of earnings management decreased after IFRS was adopted, and that strong law enforcement was an effective factor in this reduction ${ }^{24}$. Houqe, Dunstan, and Karim ${ }^{17}$ found that IFRS adoption did not affect the level of discretionary accruals in 46 countries, but that the level decreased when IFRS adoption was accompanied by a strong investor protection mechanism in the country. Based on those studies, the second hypothesis of this research is as follows:

H2: Investor protection at country level strengthens the negative correlation between IFRS adoption and the level of opportunistic earnings management.

\section{RESEARCH METHOD}

The sample in this research comprises firms in Indonesia, Malaysia, the Philippines, Taiwan, Korea, and Hong Kong, that are not in the financial and real estate industries, from 2008 to 2012. The list of firms and data was obtained from Worldscope Database. The industry classification used follows the Standard Industrial Classification (SIC). The data used are secondary data and were obtained from Thomson Reuters Datastream and International Monetary Fund. The determination of IFRS adoption in the six countries was achieved with reference to PricewaterhouseCoopers Survey 2013 and the IFRS Jurisdiction Profile. The investor protection index was obtained from World Bank Doing Business database. 
The discretionary accruals model developed by Kothari, Leone, and Wasley ${ }^{1}$ is used as the earnings management proxy. Discretionary accruals estimation is the absolute of the residual from the regression result in each year and each industry. The model is as follows:

$\frac{\text { TACCR }_{i, t}}{\text { Asset }_{i, t-1}}=\alpha_{0}+\alpha_{1} \frac{1}{\text { Asset }_{i, t-1}}+\alpha_{2} \frac{\Delta \operatorname{SALES}_{i, t}-\Delta A R_{i, t}}{\text { Asset }_{i, t-1}}+\alpha_{3} \frac{\operatorname{PPE}_{i, t}}{\text { Asset }_{i, t-1}}+\alpha_{4} R \mathrm{RAA}_{i, t}+\varepsilon_{i, t} \cdots \ldots$

where TACCR $\mathrm{it}_{\text {it }}$ is total of firm $i$ accruals in $t$ year, calculated by the difference between net income before extraordinary items and operating cash; Asset $t_{i t-1}$ is total asset of firm $i$ in $t-1$ year; $\triangle$ SALES $_{\text {it }}$ is the difference of sales of firm $i$ in $t$ and $t-1$ year; $\Delta \mathrm{AR}_{\mathrm{it}}$ is the receivables difference of firm $i$ in $t$ and $t-1$ year; $\mathrm{PPE}_{\mathrm{it}}$ is gross property plant and equipment of firm $i$ in $t$ year; $\mathrm{ROA}_{\mathrm{it}}$ is return on asset in firm $i$ and $t$ year; $\varepsilon$ is the residual value of firm $i$ in $t$ year, which is the discretionary accruals value in this research.

The first model is developed to test the impact of IFRS adoption on the decreased earnings management level, which is as follows:

$1^{\text {st }}$ Model

$\mathrm{DACCR}_{\mathrm{it}}=\beta_{0}+\beta_{1} \mathrm{IFRS}+\beta_{2} \mathrm{INVP}+\beta_{3} \mathrm{SIZE}_{\mathrm{it}}+\beta_{4} \mathrm{LEV}_{\mathrm{it}}+\beta_{5} \mathrm{GWTH}_{\mathrm{it}}+\beta_{6} \mathrm{CFO}_{\mathrm{it}}+\beta_{7} \mathrm{LAGLOSS}_{\mathrm{it}}+\beta_{8} \mathrm{GDP} \mathrm{GWTH}_{-}$ + fixed effects $+\varepsilon$

The second model is developed by considering the impact of investor protection on the correlation between IFRS adoption and earnings management. Thus, the model that is used to test the second hypothesis is as follows:

\section{$2^{\text {nd }}$ Model}

$\mathrm{DACCR}_{\mathrm{it}}=\gamma_{0}+\gamma_{1} \mathrm{IFRS}+\gamma_{2} \mathrm{INVP}+\gamma_{3} \mathrm{IFRS}^{*} \mathrm{INVP}+\gamma_{4} \mathrm{SIZE}_{\mathrm{it}}+\gamma_{5} \mathrm{LEV}_{\mathrm{it}}+\gamma_{6} \mathrm{GWTH}_{\mathrm{it}}+\gamma_{7} \mathrm{CFO}_{\mathrm{it}}+\gamma_{8} \mathrm{LAGLOSS}_{\mathrm{it}}+$ $\gamma_{9} \mathrm{GDP} \_\mathrm{GWTH}+$ fixed effects $+\varepsilon_{\mathrm{i}} \ldots . . .(3)$
DACCR $_{\text {it }}$
IFRS
: proxy for earnings management level using Kothari, Leone, and Wasley ${ }^{1}$ model
INVP : country level of investor protection index which is developed by World Bank through the Doing : dummy variable that takes the value of 1 for a given country in the years after mandatory IFRS adoption and 0 otherwise Business project on a scale of $0-10$
SIZE $_{\text {it }} \quad:$ natural logarithm of total assets for firm $i$ in year $t$
$\mathrm{LEV}_{\text {it }} \quad:$ total long-term debt/total assets for firm $i$ in year $t$
$\mathrm{GWTH}_{\mathrm{it}} \quad:$ sales growth rate, defined as the sales in year $t$ minus sales in year $t-1$ and scaled by sales in year $t-1$
$\mathrm{CFO}_{\text {it }} \quad$ : operating cash flow for firm $i$ in year $t$ scaled by total asset in year $t-1$
LAGLOSS $_{\text {it }} \quad$ : dummy variable equals 1 if net income before extraordinary items of firm $i$ in year $t-1<0$ and 0 otherwise

GDP_GWTH : GDP growth of firm $i$ country in year $t$

Fixed effects : fixed effects for year and country

\section{RESULTS AND DISCUSSIONS}

Based on the regression result of the first model, it is indicated that a firm's opportunistic earnings management level increased in the period after IFRS was adopted as the accounting standard. A positive coefficient of the IFRS variable by 0.00536 and p-value of 0.015 shows that IFRS is positively associated with the level of earnings management with a $5 \%$ significance. With this result, the first hypothesis is rejected.

This result contrasts with most of the previous studies, but is similar to a study from Callao and Jarne ${ }^{10}$. They found a higher level of discretionary accruals after IFRS adoption in 11 European countries, compared to before IFRS had been adopted. A similar result was also found by Rudra and Bhattacharjee ${ }^{25}$; they found a higher level of opportunistic earnings management after IFRS had been adopted in India.

Callao and Jarne ${ }^{10}$ also explained that the increase in discretionary accruals could be because IFRS is still in the early years of adoption. Similar to this research, their research period was also in the transition period of IFRS implementation and the IFRS adoption period, therefore, firms were likely to use this reason to take opportunistic actions as much as possible.

There are two reasons for a lower accounting quality after IFRS has been adopted according to Barth, Landsman, and Lang 6 . First, there is a possibility that IFRS is of a lower quality compared to local accounting standards, where previously management discretion over the accounting measurement to reflect a firm's economic performance is limited. The flexibility in principal is based on the view that IFRS brings a greater opportunity for management to perform earnings management. Second, there are other factors that contribute to why the quality of financial reporting might not support the use of a high-quality accounting standards. This implies that the adoption of accounting standards alone is not enough to increase accounting quality.

Several significant factors influence the level of earnings management in this research: investor protection, firm size, leverage ratio, sales growth, operating cash flow, the risk of bankruptcy, and the growth of GDP. As expected, 
investor protection has a significant negative effect on the level of earnings management. This shows that stronger investor protection in a country means a lower level of earnings management in firms within the country. This finding is supported by previous studies ${ }^{13,15}$. Firm size has a significant negative impact on the level of earnings management, which shows that the bigger the firm size is, the lower the level of earnings management. Firm size is an indicator of the importance of internal control. With strong internal control within a firm, earnings management activity can be reduced ${ }^{26}$.

Firm leverage ratio has a significant positive impact on the level of earnings management, which shows the higher the leverage ratio is, the higher a firm's tendency to manage their earnings. In accordance with the debt covenant hypothesis, firms who have a high leverage ratio tend to manage their earnings in order to avoid violating the covenant. Sales growth has a significant positive impact on earnings management, which shows that growing firms tend to perform earnings management. They manage their earnings to increase the firm's value; thus, they are able to attract investors to fulfil their financial needs ${ }^{17}$.

Operating cash flows has a significant negative impact on the level of earnings management. This result is similar to research by Iatridis and Rouvolis ${ }^{27}$, which found that firms who have relatively low operating cash flows tend to increase their accrual. Bankruptcy risk is positively associated with earnings management. It shows that if firms have incurred a loss in the previous years, they tend to manage their earnings in the next fiscal year.

GDP has a significant negative impact on earnings management. In accordance with Leuz, Nanda, and Wysocki $^{13}$, an effective law infrastructure is expensive. Thus, the economic growth rate, which indicates a country's wealth, influences the law enforcement, which could affect the level of earnings management.

The purpose of the second hypothesis is to test whether investor protection could affect the relationship between IFRS adoption and the level of earnings management. The effect could be seen from the coefficient sign and the significance of variable IFRS*INVP as a moderating variable between IFRS and investor protection. Consistent with the test in the first model, the IFRS variable has a positive coefficient with 5\% significance in the second model. Furthermore, the coefficient of the IFRS*INVP variable is -0.01848 with a p-value of 0.035 . This shows that the positive correlation of IFRS on earnings management is weakened when the country has strong investor protection. Therefore, the second hypothesis, which is that investor protection at a country level strengthens the negative correlation between IFRS adoption and opportunistic earnings management level is rejected. This research finds that the level of earnings management is higher after IFRS adoption compared to before IFRS adoption; however, the high level of earnings management is lower when the country has strong investor protection.

The existence of strong law enforcement for the rights investors or non-controlling shareholders limits the incentive for management to take actions that benefit only them or the controlling shareholders ${ }^{13}$. The reduced incentive prevents management from carrying out opportunistic earnings management because it is more difficult to hide any manipulation from investors.

Houqe, Dunstan, and Karim ${ }^{17}$ concluded that IFRS adoption alone does not increase profit quality; other factors are required that can support the IFRS implementation to achieve its objectives, and one of the factors is investor protection. The existence of incentives for management to manage their earnings, resulting in the use of accounting standards, needs to be accompanied by an enforcement mechanism and appropriate institutional regulations. This research finds that strong investor protection is needed to weaken the positive relationship between IFRS adoption and the level of opportunistic earnings management.

\section{CONCLUSION}

This research analyzes whether IFRS adoption has a negative impact on the level of opportunistic earnings management, and considers what might be the impact after investor protection is introduced at a country level. The subjects of this research are firms in six Asian countries from 2008 to 2012. The absolute discretionary accruals model developed by Kothari, Leone, and Wasley ${ }^{1}$ is used to estimate the level of earnings management.

This research finds that IFRS adoption does not decrease the level of opportunistic earnings management. On the contrary, the level of earnings management is higher after IFRS adoption compared to before IFRS adoption. This increase in earnings management is probably due to IFRS adoption being still at an early stage. The principlebased IFRS characteristic provides a broader judgment area for management. Thus, in the transition period of IFRS adoption, management may use its discretion in preparing financial statements. This result is consistent with the findings of both cross-country and single country studies, where discretionary accruals are higher following IFRS adoption ${ }^{10,25,28}$. Previous studies have argued that this result is caused by the characteristic of IFRS, which has greater flexibility through the principal basis and the use of fair value. Another cause is that the time periods used in this research are times when IFRS adoption was still in the transition period, and therefore, the management was likely to maximize their opportunist behavior.

Regarding the impact of investor protection on IFRS adoption, the level of earnings management is consistently higher following IFRS adoption. However, the positive correlation between IFRS adoption and the level of earnings management is lower, that is, weaker, if there is strong investor protection in the country. Therefore, 
strong support from law enforcement, the capital market regulator, and the government is needed to reduce the negative effect of IFRS adoption on the quality of financial reporting.

\section{REFERENCES}

[1] SP Kothari, AJ Leone, CE Wasley. Performance matched discretionary accrual. Journal of Accounting and Economics, 39 (2005) 163197.

[2] H Daske, L Hail, C Leuz, R Verdi. Mandatory IFRS reporting around the world: Early evidence on the economic consequences. Journal of Accounting Research, 46(5) (2008) 1085-1142.

[3] MC Jensen, W Meckling. Theory of the firm: Managerial behavior, agency costs and ownership structure. Journal of Financial Economics, 3 (1976) 305-360.

[4] SV Siregar, S Utama. Type of earnings management and the effect of ownership structure, firm size, and corporate-governance practices: Evidence from Indonesia. The International Journal of Accounting, 43(1) (2008) 1-27.

[5] PE Dimitropoulos, D Asteriou, D Kousenidis, S Leventis. The impact of IFRS on accounting quality: Evidence from Greece. Advances in Accounting, 29(1) (2013) 108-123.

[6] ME Barth, WR Landsman, MH Lang. International accounting standards and accounting quality. Journal of Accounting Research, 46(3) (2008) 467-498.

[7] D Zéghal, S Chtourou, YM Sellami. An analysis of the effect of mandatory adoption of IAS/IFRS on earnings management. Journal of International Accounting, Auditing and Taxation, 20 (2011) 61-72.

[8] R Ewert, A Wagenhofer. Economic effects of tightening accounting standards to restrict earnings management. The Accounting Review, 80(4) (2005) 1101-1124.

[9] B Van Tendeloo, A Vanstraelen. Earnings management under German GAAP versus IFRS. European Accounting Review, 14(1) (2005) $155-180$.

[10] S Callao, JI Jarne. Have IFRS affected earnings management in the European Union?. Accounting in Europe, 7(2) (2010) 159-189.

[11] T Jeanjean, H Stolowy. Do accounting standards matter? An exploratory analysis of earnings management before and after IFRS adoption. Journal of Accounting and Public Policy, 27(6) (2008) 480-494.

[12] NS Soderstrom, KJ Sun. IFRS adoption and accounting quality: A review. European Accounting Review, 16(4) (2007) 675-702.

[13] C Leuz, D Nanda, PD Wysocki. Earnings management and investor protection: An international comparison. Journal of Financial Economics, 69 (2003) 505-527.

[14] SY Fung, L Su, RJ Gul. Investor legal protection and earnings management: A study of Chinese H-shares and Hong Kong shares. Journal of Accounting and Public Policy, 32(5) (2013) 392-409.

[15] S Nabar, KK Boonlert-U-Thai. Earnings management, investor protection, and national culture. Journal of International Accounting Research, 6(2) (2007) 35-54.

[16] CH Shen, HL Chih. Investor protection, prospect theory, and earnings management: An international comparison of the banking industry, Journal of Banking \& Finance, 29(10) (2005) 2675-2697.

[17] MN Houqe, T Zijl, K Dunstan, AW Karim. The effect of IFRS adoption and investor protection on earnings quality around the world. The International Journal of Accounting, 47 (2012) 333-355.

[18] S Djankov, R La Porta, F Lopez-de-Silanes, A Shleifer. The law and economics of self-dealing. Journal of Financial Economics, 88 (2008) 430-465.

[19] FD Choi, GK Meek. International Accounting. Prentice Hall, New Jersey (2011).

[20] K Ramanna, E Sletten. Why Do Countries Adopt International Financial Reporting Standards?. Working Papers, Harvard Business School (2009).

[21] OK Hope, J Jin, T Kang. Empirical evidence on jurisdictions that adopt IFRS. Journal of International Accounting Research, 5(2) (2006) 1-20.

[22] V Palea. IAS/IFRS and financial reporting quality: Lessons. China Journal of Accounting Research, 6 (2013) 247-263.

[23] RM Bushman, JD Piotroski. Financial reporting incentives for conservative accounting: The influence of legal and political institutions. Journal of Accounting and Economics, 42 (2006) 107-148.

[24] L Cai, A Rahman, S Courtenay. The Effect of IFRS and Its Enforcement on Earnings Management: An International Comparison. Working Paper, Massey University (2008).

[25] T Rudra, DC Bhattacharjee. Does IFRS influence earnings management? Evidence from India. Journal of Management Research, 4(1) (2012).

[26] ML DeFond, J Jiambalvo. Debt covenant violation and manipulation of accruals. Journal of Accounting \& Economics, 17(1/2) (1994) $145-176$.

[27] G Iatridis, S Rouvolis. The post-adoption effects of the implementation of International Financial Reporting Standards in Greece. Journal of International Accounting, Auditing and Taxation, 19(1) (2010) 55-65.

[28] C Lopes, A Cerqueira, E Brandão. Impact of IFRS adoption on accounting quality in European firms. Journal of Modern Accounting and Auditing, 6(9) (2010) 20-31. 